\title{
The Courses and Policy Environment of E-Commerce Development in
}

\author{
China \\ YAO Lin \\ School of Economics and Resource Management, Beijing Normal University \\ darlin017@163.com
}

\begin{abstract}
China's e-commerce industry has went through 21 years since China's first e-commerce enterprise established in 1996. With the rapid development of Internet and communication technology, e-commerce has penetrated into enterprises' production and people's life, and continued to exert its great potential when combining with traditional manufacturing industry. There is no doubt that e-commerce has greatly increased the efficiency of society functions. This paper cards the courses and policy environment of e-commerce development in China, identifies four stages for China's e-commerce development, which are "initial stage, accelerated stage, standardization stage and globalization stage". At the same time, this paper describes three different characteristics of current China's e-commerce and summarizes five policy focus for e-commerce. Based on the previous analysis and descriptions, this paper puts forward conclusions that China's e-commerce sector will usher in a new round expansion on global scale, and the Chinese government will play a key and active role in promoting it. In addition, this paper warns these China's e-commerce enterprises to actively prevent unknown risk from home and abroad in their business expansion, the government ought to listen to e-commerce companies to deal with their specific difficulties.
\end{abstract}

\section{Keywords}

China's E-Commerce; Development Courses; Policy Environment.

\section{Academic Discipline and Sub-Disciplines}

Business Economics; Marketing.

\section{TYPE (METHOD/APPROACH)}

Historical Inquiry; Interview.

\section{Introduction}

The Internet came to China in 1994, and in the past 20 years, it has penetrated the country's industry and commercial sectors. Fundamental changes brought by the Internet have been incorporated in the operations of traditional industry markets. In recent years, China's e-commerce sector has demonstrated an explosive growth momentum. New innovations brought about by the application of e-commerce technologies have stimulated entrepreneurship, to be benefit of SMEs. At the same time, China's cross-border e-commerce is opening up with the open strategy of "Going global and bringing-in", which has become a new engine of China's economic development.

\section{The Courses of China's E-Commerce Development}

The Government of China has played a key role in development process, in terms of creating an environment for e-commerce to thrive and putting in place regulations and policies to support the sector as it has developed. Researchers have described China's e-commerce development in a series of phases. Based on the development of the main e-commerce platforms in China, MAO Yuxin and ZHAO Liang (2015) cite six phases: germination, growth, accelerate, mature, outbreak, and transformation. WANG Baoyi (2017) writes that, from the perspective of industry economic theory cycle, China's e-commerce evolution has four periods: germination, growth, eruption and integration. QI Ming and SUN 
Zhongtao (2017) also identify four stages: independent, platform, ecological and value. Based on the above research, this study divides e-commerce development into four stages marked by milestones and major policies.

\subsection{The initial stage}

During the initial stage of China's e-business, 1996 to 2000, a small number of innovators considered that the traditional business model can be combined with the Internet, bringing huge business opportunities and profits, and the first Chinese e-commerce enterprise emerge. According to statistics, $5.2 \%$ of the current e-commerce platforms are established at this time.

The first B2B e-commerce business in China, Nanjing Focus Technology Development Company was established in Southeast University in January 1996. The first vertical chemical website, directly providing in-depth information on chemicals and related services was launched in October 1997 as China's first vertical B2B site. China's first e-commerce website providers followed in 1999, many of which are the mainstay of China's e-commerce today. The 8848 website, the earliest domestic B2C e-commerce site, and Alibaba, whose main business was B2B, were also established in 1999. In the same year, Dangdang started providing the first online bookstore service, while the China Merchants Bank and China Construction Bank opened online banking businesses, making online payment possible for the first time. In 2000, Joyo, the B2C industry leader in China, was established. In April 2000, HC International launched a HC business website, today known as the $\mathrm{HC}$ network. Since, the market layouts that Ali dominated the market in South of China and HC dominated the north market in china were formed.

On 21 June 2000, certificated by the government, the China Electronic Commerce Association was officially established. This marked not only recognition of e-commerce as a specific industry, but also marks e-commerce's accelerated development.

In this phase, the e-commerce industry faced three main problems. First, Internet users in China numbered only four million, limiting the e-commerce market. Second, logistics and distribution networks were not fully in place. Third, there was a lack of confidence in the online payment system and distrust of long-distance purchasing.

\subsection{The accelerated stage}

The early 2000s ushered in an accelerated stage of China's e-commerce, during which the sector expanded from enterprise services to personal services, becoming an important trading channel for a large number of enterprises and consumers. It is also a key period in online retail development. According to statistics from the China Internet Network Information Center (CNNIC), the number of Internet users in China reached 210 million people by December 2007, of which 46.4 million were using online shopping sites, accounting for $22.1 \%$ of Internet users. The amount spent on online shopping reached 56.1 billion yuan in the same year. The period saw a huge rise in the number of Internet users.

In 2002, the US C2C e-commerce company eBay bought a 33\% stake of Each Net for US\$30m, marking the first foreign capital to enter China's e-commerce sector. In May 2003, Alibaba invested 100 million yuan to establish Taobao, its C2C business model. The establishment of Taobao set the stage for China's e-commerce industry. Online commerce developed rapidly during this time. In August 2004, Amazon, a large US B2C platform, bought Joyo Net for US\$75m. The Joyo name was subsequently changed to "Amazon". In January 2004, "Jingdong Multimedia Network" was established, as an e-commerce platform able to rival Ali in the B2C sector. In October 2004, Alibaba launched Alipay using a third-party guarantee to promote online payment services to improve the trust deficit in online payments and long-distance purchases. In June of the same year, the first network business conference was held in Hangzhou and, with it, the large scale C2C model came to China. In 2005, Taobao signed a logistics supply agreement with YT Express. The three main problems in the early development of China's e-commerce were tackled at this stage. 
At the same time, new regulations came into force, including the "Electronic Signature Law of the People's Republic of China", "Self-discipline Norms of Online Trading Platform", among others. In 2015, the State Council issued "Several Opinions on Accelerating the Development of Electronic Commerce". The State Development and Reform Commission, the State Council Information Office jointly issued the "E-commerce Development Five-Year Plan" in 2007, which is the first time that the State Council issued a national e-commerce development plan at the national policy level. The promulgation of the plan marked the shift in e-commerce in China from the accelerated development stage to the standardization stage.

\subsection{The standardization stage}

The standardization stage of China's e-commerce lasted from 2008 to 2014 . On the one hand, e-commerce was benefitting from China's huge consumer market. According to CNNIC statistics, the scale of China's online shopping reached 128.18 billion yuan in June 2008 and it surged to 1.3 trillion yuan in 2012. In addition, the government continued to launch e-commerce regulatory policies. The national policy management system of the e-commerce industry gradually formed.

Key policies to promote e-commerce development in China appeared during this time and most government departments launched policy management systems for e-commerce. In 2009, the Ministry of Commerce issued the "e-commerce model specification" and "online shopping service standard". The State Council underpinned its support for e-commerce in the 2010 "Government Work Report". In the same year, the State Administration for Industry and Commerce issued "Online commodity trading and relevant service behavior management interim measures". In 2011, the State Council formulated "the Guiding Opinions on the Development of E-Commerce at the 12th Five-Year Plan", "the Guidance on the Establishment of National E-Commerce Demonstration Base", "the Third Party E-Commerce Transactions Platform Service Specification". In May 2011, the People's Bank of China announced the first 27 enterprises granted permission for payment transactions. On 27 December 2013, the NPC Financial and Economic Committee organized a conference on establishing an e-commerce law drafting group and established a timetable for China's e-commerce legislation. The NPC required that the drafting group should prepare a legislative outline by December 2014. In 2014, the State Administration for Industry and Commerce and the Ministry of Industry and Information Technology jointly issued "Opinions on strengthening the supervision and cooperation of domestic online transactions, actively promoting the development of e-commerce", and the State Administration for Industry and Commerce issued "network transaction management approach". The General Administration of Quality Supervision, Inspection and Quarantine issued the "e-commerce work product quality improvement action plan". The People's Bank of China issued "Guidance on the development of mobile payment business of People's Bank of China " and an "Announcement on the strengthening the management of commercial banks and third party payment mechanisms cooperation business". The State Post Bureau, the Ministry of Finance and the Ministry of Commerce jointly issued "Relevant issues on the Pilot Project of the coordinated development of e-commerce and logistics express". The Ministry of Human Resources and Social Security issued "the Notice on the Entrepreneurship Leadership Program for National University Students". The China Food and Drug Administration requested public comments on "the supervision and management approach of Internet food and drug business". The formation of a policy management system marked the standardization of e-commerce in China.

With an increasing number of global Internet users, as well as improved systems of cross-border payment, logistics and other services, China's cross-border e-commerce retail overseas consumer business $(\mathrm{B} 2 \mathrm{C} / \mathrm{C} 2 \mathrm{C})$ was booming. A number of cross-border e-commerce platforms, such as Ali Express, flourished during this period. Cross-border e-commerce retail business became a new model to further open oversea markets. A large number of SMEs in China and network operators began to directly participate in international trade, which was also undergoing tremendous changes.

\subsection{The globalization stage}

On the basis of previous policies and regulations, the development of China's e-commerce SMEs has gradually moved on from a "brutal growth" stage, exhibiting an integrated and orderly development trend. Most regions in China implemented a 
cross-border e-commerce development strategy in 2014. A large number of cross-border e-commerce retail sales platforms saw explosive growth during this period, such as Tamll.HK, Kaola, Jumei, Matou, and Red.

In April 2014, Jumei shares were traded on the New York Stock Exchange. Jingdong went public on Nasdaq on May, becoming the second largest business platform in China. Alibaba was listed on the New York Stock Exchange on September and became the largest IPO in American history. It could be said that 2014 was the most influential year for China's global e-commerce. The majority of domestic business platforms carried out their own global capital development strategy. At the same time, many regions of China started to develop cross-border e-commerce. Zhejiang Province, for instance, established a cross-border e-commerce work mechanism, with Hangzhou and Ningbo as the main pilots for a management system and set of rules on global cross-border e-commerce, especially a "single window" for logistical and legal matters. Guangzhou Province created the first cross-border e-commerce model city in South China. The local government formulated a special Refund Guarantee Fund to support cross-border e-commerce. Fujian Province's "Cross-border trade e-commerce work implementation programme in Fujian Province" focused on the implementation of e-commerce cooperation between Fujian and Taiwan. Gansu Province established a cross-border e-commerce platform to create an "online Silk Road" selling special local products with the support of Holmes Border Cooperation Center.

Guangxi Province promoted cooperation between China and Vietnam through e-commerce trade and cooperation. Heilongjiang Province listed the Suifenhe border economic cooperation zone as a base of cross-border e-commerce development and focused on opening cross-border trade with Russia. The "E-commerce development plan" in Xinjiang Bazhou was designed to facilitate exports to the Middle East and East Asia.

Nine provinces of China have international borders. Six of them prepared detail plans for the development of cross-border e-commerce. Three launched support policies for supporting the development of cross-border e-commerce. June 2015, the State Council issued "Guidance on the promotion of cross-border e-commerce healthy and rapid development", designed to accelerate the development of cross-border e-commerce in China. At the international level, the Chinese delegation formally entered the discussion process at the $30^{\text {th }}$ session of the third working group of the United Nations Commission on International Trade Law, held in Vienna on 20 October 2014. The "ODR- integration vision of track one and track twoproposal from Chinese delegation" was the first accepted by the UN commission since China started to participate in drafting the working group's "Cross-border E-Commerce Transaction Dispute Resolution: Rules of Procedure". In the same year, China proposed the "Asia-Pacific Economic Cooperation and Development Initiative for E-Commerce" at the 22nd APEC Economic Leaders' Informal Meeting held in Beijing on 11 November, which was unanimously approved.

\section{The Status of E-Commerce in China}

E-commerce in China has become an important driving force in the economy, and an important starting point for economic restructuring and development. At present, the development of e-commerce in China can be characterized in the following way:

\subsection{Explosive growth in e-commerce transactions}

According to statistics from the China E-Commerce Report, the Ali Research Institute and the Avatar Large Data Processing Center, China's total e-commerce transactions reached 28.9 trillion yuan in 2016 (excluding Hong Kong, Macao and Taiwan), an increase of $38.9 \%$ compared to 20.8 trillion in 2015. According to calculations by the research group, the average annual growth rate of China's e-commerce transactions is $38.2 \%$ in the past five years (Figure 1). A single-day trading volume on the 11 November 2016 shopping festival was more than 120.7 billion yuan and set a record of 50 billion yuan trading value in two and a half hours. With its high growth trend, e-commerce had become a new bright spot in China's economy. In 2014, with the NDRC and other departments of government, the Ministry of Commerce carried out innovation work plan for national e-commerce demonstration cities, setting up e-commerce model cities in 53 regions, identifying 34 demonstration bases and 100 demonstration enterprises. 


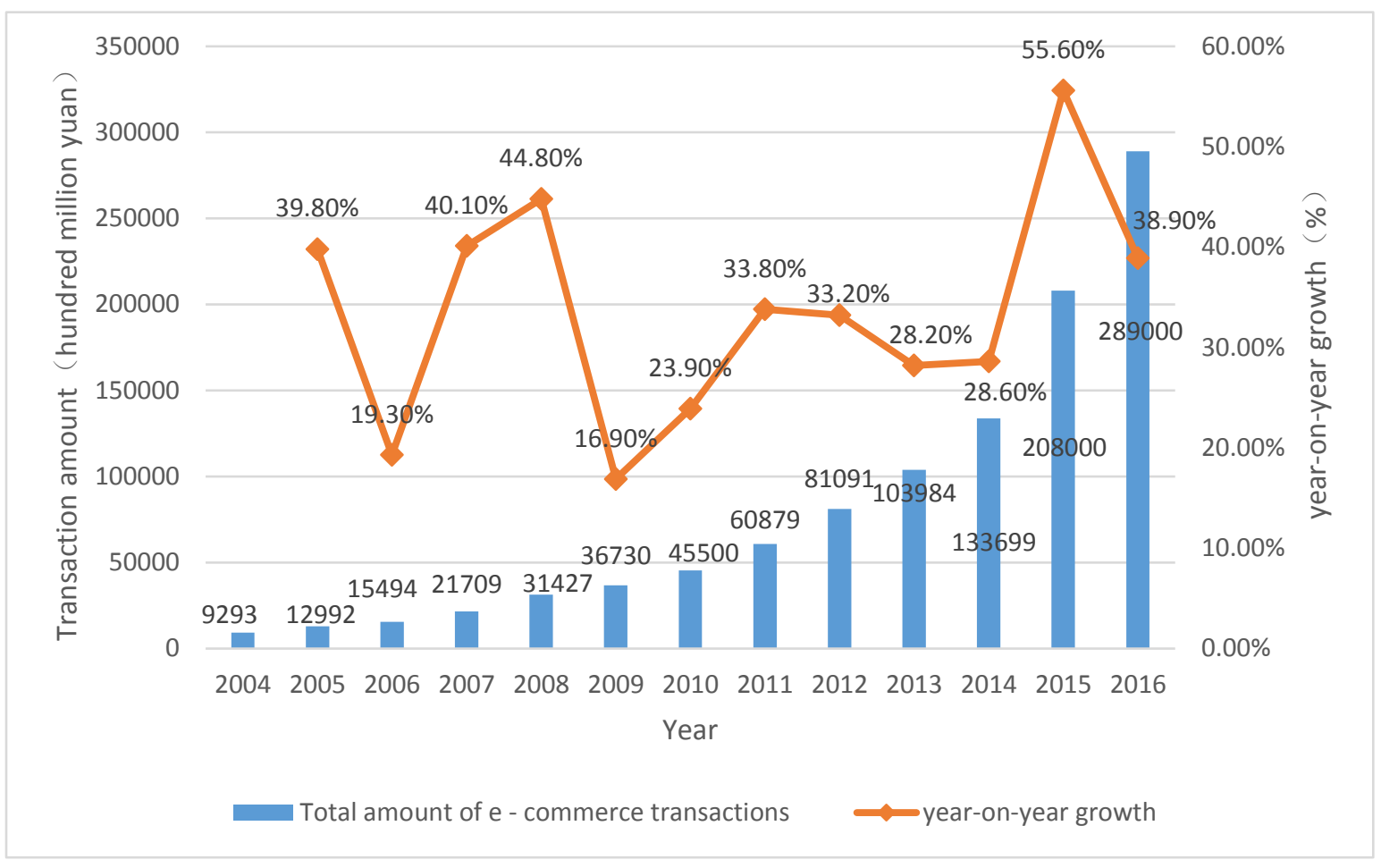

Source: China's E-Commerce Report, Data of 2015 and 2016 is from Ali Research Institute and Avatar Big Data Processing Center.

Fig.1: China's total e-commerce transactions from 2004 to 2016

\subsection{A strong trend of online shopping}

According to data provided by the Ali Research Institute, China's online retail trade volume was 5,155.6 billion yuan in 2016, with the growth rate of more than $32.2 \%$. The average annual growth rate in the past five years was $45.94 \%$. China's online retail sales began to surge in 2009 and 2010, during which the growth rate doubled and redoubled (Figure 2). Compared with the growth rates of online shopping and the total retail sales of social consumer goods, the former has been $87.8 \%$ since 2011 and the latter $14.7 \%$. In 2001 , online shopping accounted for only $0.01 \%$ of total retail sales of consumer goods. After 15 years' continuous development, the proportion was $14.3 \%$ in 2016 . From the ratio of online shopping to the total retail sales of consumer goods, e-commerce had gone through three periods: breaking through the 100 billion yuan mark and accounting for more than 1\% in 2008; reached one trillion yuan (5\%) in 2012; and two trillion yuan (10\%) in 2014 (Table 1).

The $\mathrm{B} 2 \mathrm{C}$ model rose year after year. The proportion of $\mathrm{B} 2 \mathrm{C}$ accounted for by $\mathrm{B} 2 \mathrm{C}$ and $\mathrm{C} 2 \mathrm{C}$ has increased by more than $50 \%$ since 2015. According to iResearch consulting, B2C will become China's main e-commerce model in the future. Another noteworthy change is the dramatic increase in the proportion of mobile e-commerce purchases, from $1.5 \%$ in 2011 to $68.2 \%$ in 2016, thanks to the popularity of smart phones (Table 2). 


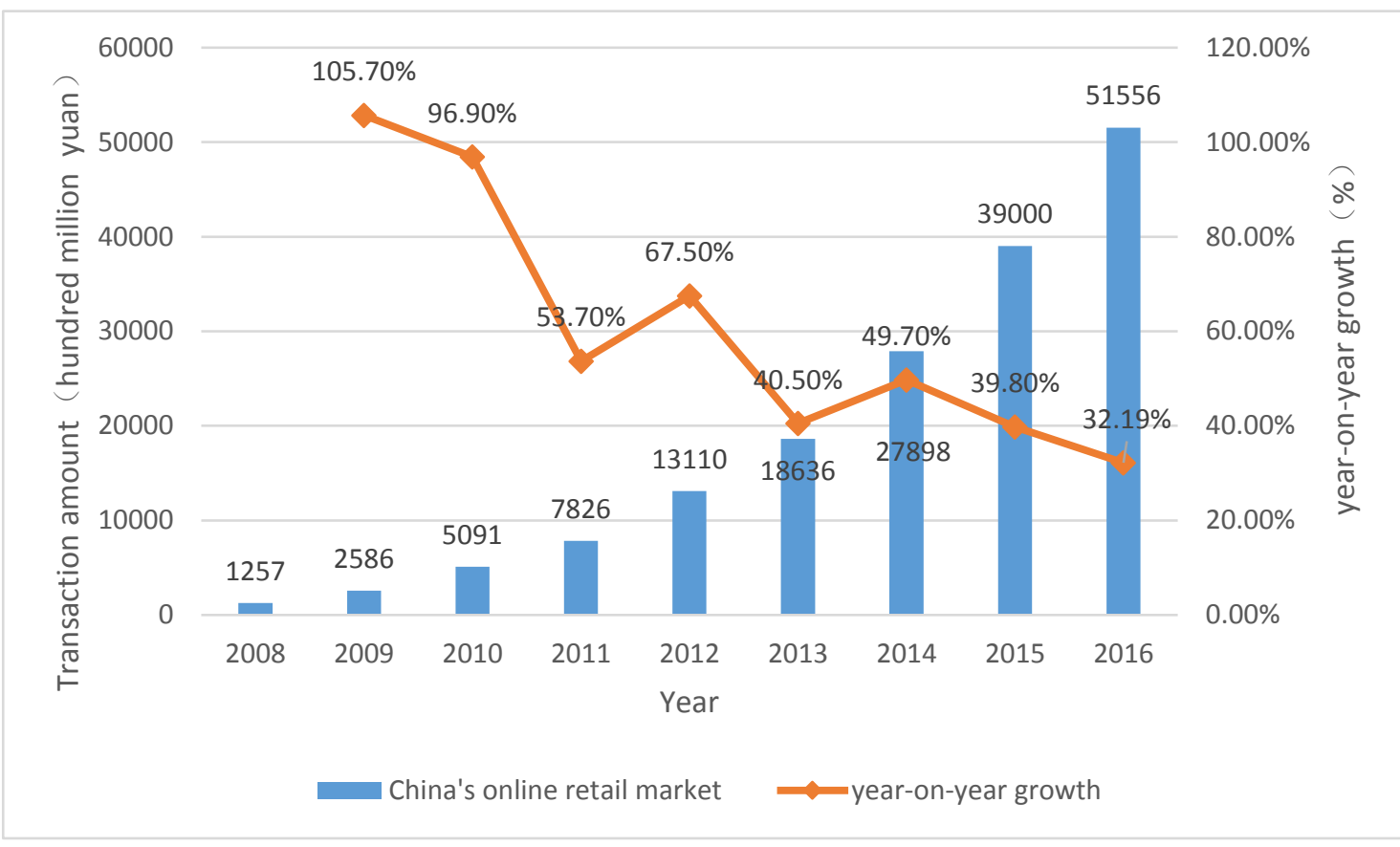

Source: China's E-Commerce Report. Ali Research Institute provided the data of 2016.

Fig. 2: Trading volume of China's online retail from 2008 to 2016

Table 1. Statistics of China's total retail sales and social consumer goods

\begin{tabular}{|c|c|c|c|c|c|}
\hline Year & $\begin{array}{c}\text { Online } \\
\text { shopping } \\
\text { scale / billion } \\
\text { Yuan }\end{array}$ & Growth rate & $\begin{array}{c}\text { Social retail } \\
\text { goods / } \\
\text { billion Yuan }\end{array}$ & Growth rate & $\begin{array}{c}\text { Proportion of } \\
\text { online } \\
\text { shopping }\end{array}$ \\
\hline 2001 & 0.6 & - & 4305.54 & - & $0.01 \%$ \\
\hline 2002 & 1.7 & $196.67 \%$ & 4813.59 & $11.80 \%$ & $0.04 \%$ \\
\hline 2003 & 3.9 & $119.66 \%$ & 5251.63 & $9.10 \%$ & $0 . .07 \%$ \\
\hline 2004 & 8.0 & $106.91 \%$ & 5950.10 & $13.30 \%$ & $0.14 \%$ \\
\hline 2005 & 19.3 & $138.69 \%$ & 6835.26 & $14.88 \%$ & $0.28 \%$ \\
\hline 2006 & 21.3 & $61.57 \%$ & 7914.52 & $15.79 \%$ & $0.39 \%$ \\
\hline 2007 & 56.1 & $79.81 \%$ & 9357.16 & $18.23 \%$ & $0.60 \%$ \\
\hline 2008 & 125.7 & $128.48 \%$ & 11483.01 & $22.72 \%$ & $1.12 \%$ \\
\hline 2009 & 258.6 & $105.7 \%$ & 13267.84 & $15.54 \%$ & $1.98 \%$ \\
\hline 2010 & 509.1 & $96.9 \%$ & 15699.84 & $18.33 \%$ & $2.94 \%$ \\
\hline 2011 & 782.6 & $53.7 \%$ & 18720.60 & $19.24 \%$ & $4.19 \%$ \\
\hline 2012 & 1311.0 & $67.5 \%$ & 21443.30 & $14.54 \%$ & $5.54 \%$ \\
\hline 2013 & 1863.6 & $40.5 \%$ & 24284.30 & $13.25 \%$ & $7.79 \%$ \\
\hline
\end{tabular}




\begin{tabular}{|c|c|c|c|c|c|}
\hline 2014 & 2789.8 & $49.7 \%$ & 27189.60 & $11.96 \%$ & $10.26 \%$ \\
\hline 2015 & 3900.0 & $39.8 \%$ & 30093.10 & $10.68 \%$ & $12.60 \%$ \\
\hline 2016 & 5156.6 & $32.19 \%$ & $\mathrm{e} 33231.6$ & $\mathrm{e} 10.43 \%$ & $\mathrm{e} 15.52 \%$ \\
\hline
\end{tabular}

Note: Data is from the National Bureau of Statistics of China, relevant research reports and research institutes.

Table 2. Changes and trends of network retail related indicators from 2011 to 2018

\begin{tabular}{|c|c|c|c|c|c|c|c|c|}
\hline Year & $\begin{array}{l}\text { Online } \\
\text { shopping } \\
\text { scale / } \\
\text { trillion } \\
\text { Yuan }\end{array}$ & $\begin{array}{l}\text { Online } \\
\text { shopping } \\
\text { proportion } \\
\text { of social } \\
\text { retail } \\
\text { sales }\end{array}$ & $\begin{array}{l}\text { Online } \\
\text { shoppers } \\
\text { scale/ } \\
\text { hundred } \\
\text { million } \\
\text { people }\end{array}$ & $\begin{array}{l}\text { Online } \\
\text { shoppers' } \\
\text { proportion } \\
\text { of Internet } \\
\text { users }\end{array}$ & $\begin{array}{l}\text { Per capita } \\
\text { consumption } \\
\text { of online } \\
\text { shopping/Yuan }\end{array}$ & $\begin{array}{l}\text { Online } \\
\text { shopping } \\
\text { growth rate of } \\
\text { per capita } \\
\text { consumption }\end{array}$ & $\mathrm{B} 2 \mathrm{C} /(\mathrm{B} 2 \mathrm{C}+\mathrm{C} 2 \mathrm{C})$ & $\begin{array}{l}\text { Proportion } \\
\text { of mobile } \\
\text { shopping }\end{array}$ \\
\hline 2012 & 1.2 & $5.5 \%$ & 2.4 & $42.9 \%$ & 4904.9 & $21.3 \%$ & $34.6 \%$ & $5.8 \%$ \\
\hline 2013 & 1.9 & $7.8 \%$ & 3.0 & $48.9 \%$ & 6268.8 & $27.8 \%$ & $40.4 \%$ & $14.5 \%$ \\
\hline 2014 & 2.8 & $10.3 \%$ & 3.6 & $55.7 \%$ & 7722.0 & $23.2 \%$ & $45.2 \%$ & $33.8 \%$ \\
\hline e2017 & 6.2 & $17.1 \%$ & 5.0 & $68.0 \%$ & 12539.9 & $15.8 \%$ & $64.0 \%$ & $72.8 \%$ \\
\hline e2018 & 7.5 & $19.2 \%$ & 5.3 & $71.5 \%$ & 14240.7 & $13.6 \%$ & $68.1 \%$ & $73.8 \%$ \\
\hline
\end{tabular}

Note: The data comes from China E-Commerce Report and Ali Research Institute. The forecast data marked "e" is from iResearch Institute.

\subsection{0 model penetrated to traditional industries quickly}

The $\mathrm{O} 2 \mathrm{O}$ model is the use of the Internet to combine offline goods or services with online goods, generating orders online and finishing transactions and payments offline. In 2014, department stores began to focus on O2O. Rt-mart supermarket established a B2C online website-_flying cow net". The Net of Suning Custom Shopping services the customers online and customers could use mobile client to buy products. Wangfujing Department Store launched a pilot project of WeChat shopping in Beijing. Within 5 years since 2011, O2O users' penetration rate of the Net of Wuhan Leisure was $35.9 \%$. Shenzhen online flight booking was up to $23 \%$; Beijing online car service user penetration rate was $19.4 \%$. In the promotion of $\mathrm{O} 2 \mathrm{O}$, a large number of traditional Chinese enterprises began to use the Internet to conduct business, helping to increase $\mathrm{O} 2 \mathrm{O}$ penetration.

\subsection{The advantages of agriculture e-commerce}

Agriculture has been a particular beneficiary of e-commerce. The government's "Opinions on the deepening of rural reform to accelerate the modernization of agriculture" emphasized that strengthening the e-commerce platform for agricultural products. The Ministry of Commerce and the Ministry of Finance jointly launched the "e-commerce into the rural comprehensive demonstration project", carrying out e-commerce application demonstration projects in 56 districts of eight provinces and autonomous regions. A national agricultural products information service platform linked the purchase of agricultural products and sale through cooperation with large-scale agricultural products market and chain supermarkets. Fresh food e-commerce platforms, such as Taobao and Jingdong, joined up with vertical e-businesses. For example, SF 
Express formed a fresh food venture with China National Cereals, Oils and Foodstuffs Corporation. At the same time, farm to consumer (F2C), consumer to business (C2B), consumer ordering from farm (C2F), community supporting agriculture (CSA) and other new models have also appeared.

\section{The Policy Focus and Environment of E-Commerce Development in China}

In recent years, the Chinese government has attached great importance to the development of e-commerce, which it regards as an important instrument for economic transition and opening-up. With the rapidly changing trade environment, the government, ministries and regions have launched policies and regulations and a system of retail e-commerce regulation has been gradually established.

Over viewing e-commerce policies, the study finds that the Chinese government adheres to the following key points in e-commerce:

\subsection{Lowering the access threshold to support e-commerce infrastructure construction.}

The government strongly supports the construction of e-commerce platforms, and has been simplifying procedures of capital registration, reducing barriers to access and cleaning up existing pre-approval issues in the field of e-commerce. Authorities are supporting the establishment of logistical terminals and intelligent logistical platforms, promoting the construction of trans-regional and cross-industry logistical platforms, supporting infrastructure construction of express distributing stations, and encouraging community management systems, village information service stations, as well as stores to provide express delivery services. Chinese central government requires each level of government to reserve land for logistical warehousing in town planning, to plan for land utilization and supply, to guide social capital to invest in the construction of storage facilities, and to encourage express enterprises' to take "warehouse distribution integration" services. The government focused on the development of e-commerce in the field of agriculture especially by establishing agricultural chain logistics and carrying out e-commerce demonstration pilot projects in rural areas.

\subsection{Funding and strengthening financial support to e-commerce.}

Government policy includes a tax incentive reform programme for high-tech SMEs to replace business tax with a value-added tax and a multi-channel financing mechanism to support e-commerce companies. The government encourages all commercial banks and other financial actors to launch intangible assets, real estate pledges and other forms of financing services to e-commerce SMEs. It also guides investment funds to strengthen support for e-commerce start-ups.

\subsection{Strengthening credibility and promoting the credit system.}

The government is actively strengthening the construction of an e-commerce credit system. A proposal to establish a unified and standardized e-commerce credit information management system was made by the government, including all credit information of stakeholders. The government is also devoted to providing credit information of legal persons, trademarks and product quality of e-commerce companies to the public. At the same time, the relevant government departments jointly support a penalty mechanism by forwarding commercial credit evaluations. Based on the credit evaluation of sellers, the government can monitor companies with poor credit ratings, helping to prevent fake e-commerce goods.

There are other measures to establish a credit system, including e-commerce network ID cards and a Real-Name system, encouraging the development of trusted certificate services, developing public services of credible security in e-commerce transactions, improving the e-commerce credit service security system, and promoting the application of credit investigation, evaluation, guarantee and other third-party credit services in electronic commerce. 


\subsection{Risk prevention by building e-commercial security defense.}

The government requires e-commerce enterprises to be in accordance with information security protection regulations and technical standards. It is vital to build a system of e-commerce transaction security management to clarify the responsibilities and obligations of each partner in an e-commerce transaction. To reduce risk, the government has promoted cross recognition of digital certificates and application of digital certificates among electronic certification authorities. The standardized management mechanism of electronic contracts was also constructed to improve data security. A supervising regulatory body could cover different government sectors as well as different regions and a risk monitoring body could conduct online spot checks. The government also aims at cracking down on fake and poor quality goods, network theft, and other illegal online trading activities.

\subsection{Perfecting the legal system by strengthening laws.}

Against a background of the rapidly changing business environment, the government is amending existing laws based on public feedback. The government has revised the Advertising Law, Consumer's Interest Protection Law and other laws based on the requirements of e-commerce. At the same time, the government has clarified the legal rights of electronic bills, electronic contracts, electronic inspection and other kinds of electronic transaction documents. In December 2013, the drafting work of the E-commerce Law of the People's Republic of China was launched, and was put into the Twelfth National People's Congress' legislative plan for the next five years. The bill collected public comments and suggestions from 27 December 2016 to 26 January 2017. In addition, the State Administration for Industry and Commerce, the Ministry of Industry and Information Technology, the Ministry of Commerce, and other relevant ministries, issued rules and regulations concerning logistics management, product quality, network transactions and consumer complaints. The government also proposed to research basic product standards in e-commerce, and participates in the setting of international e-commerce standards.

\section{Summary and Enlightenment}

Based on the previous analysis of China's e-commerce, we puts forward conclusions and predictions as follows:

(1) The Chinese government has attached great importance to the development of the e-commerce industry and consistently and actively supported it.

From the first day that e-commerce came into China, Chinese government has consistently showed their supportive attitude in spite of its great challenges to offline retailing. Government issued laws and regulations one by one, trying to be in accordance with the rapid changing situation of e-commerce. Especially in the issue regarding third party settlement and payment, the government gives an inclusive attitude towards it. Recently, central government clearly announced that e-commerce would be treated as an important impetus for the development of the national economy and would give full support to their overseas expansion.

(2) China's e-commerce sector will usher in a new round expansion on global scale.

E-commerce has a very high coverage rate in Chinese people and now the market is close to saturation. Further market expansion could be only occurred overseas. E-commerce is likely to be the first sector to benefit from the Belt and Road initiative and eWTP initiative, which will be important driving force pushing China's e-commerce enterprises' global layout. That must bring great opportunities for China's and other countries' economy.

On the other hand, this paper would like to remind these China's e-commerce companies of taking notice of business risk as well as formulate policy recommendations to remove enterprises' specific barriers.

(1) China's e-commerce enterprises should enhance the competence in fending off the unknown business risks regarding their expansion overseas. Risks not only come from external environment but also from internal business running with 
company's expansion in scale and scope. Foreign policy changes and the cultural differences between home and abroad are all the potential risks e-commerce companies may face, which need to early pre-judge and prevent.

(2) Government shall continue to throw its full weight behind e-commerce sector, paying more attention to specific difficulties enterprises have. In terms of the top-level design, relevant laws and industry plan were issued in succession and tended to perfection, but there still remains lots of specific and detailed problems. The main tasks for government should be listening to e-commerce enterprises' voice, removing their every tiny barriers and maximizing the government's support.

\section{REFERENCES}

1. Ministry of Commerce of the People's Republic of China, 2015. China's E-Commerce Report. China Commerce and Trade Press.

2. Qi Ming, Sun Zhongtao, 2017. "Research on the Evolution, Effectiveness and Trends of Chinese E-Commerce Business Model”. Industrial Economics.

3. Wang Wailian, Wang Mingyu, Liu Shuzhen. 2013. "China's Cross-border E-Commerce Status Analysis and Recommendations", E-Commerce.

4. Ali Research Institute, Ali Cross-border Electronic Business Research Center, 2016. The Future of Trade: Cross-border Electronic Business Connects the World.

5. Wang Baoyi, 2017. "The Evolution, Competitive Situation and Development Trends of China's E-Commerce Online Retail Industry", China Business and Market (Volume 31, No. 4).

6. Zheng Rushi, 2014. "The Experience of China's E-Commerce B2C Enterprises' Development Trends and Business Strategies”, China E-commerce, Volume 17 (12).

7. Tang Bingyong, Xiong Li, 2017. "China's Cross-Border E-Commerce Development Report 2015-2016”, Chemical Industry Press.

8. Pan Yuxiang, 2017. "China's Cross-border E-Commerce Development Status and Countermeasures Analysis", Economic Research Guide, 315th issue.

9. Mao Yuxin, Zhao Liang, 2016. "Big Data Age - Research on Frontier Issues of E-Commerce Ethics", Northeastern University Press.

\section{Author' biography}

YAO Lin, Master Degree Candidate in School of Economic and Resource Management at Beijing Normal University. He majors in regional economics, and his research area is regional green development.

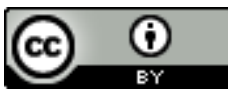

This work is licensed under a Creative Commons Attribution 4.0 International License. 